\title{
A COMPARATIVE STUDY OF TREATMENT MODALITIES FOR PSEUDOCYST OF PINNA IN A TEACHING HOSPITAL
}

\author{
Santosh Kumar Pani ${ }^{1}$, Saumya Ranjan Das², Debabrata Panigrahi ${ }^{3}$
}

${ }^{1}$ Associate Professor, Department of ENT, Institute of Medical Sciences and SUM Hospital, Siksha 'O' Anusandhan University, Odisha. 2Professor, Department of ENT, Institute of Medical Sciences and SUM Hospital, Siksha 'O' Anusandhan University, Bhubaneswar, Odisha.

3Professor, Department of ENT, Institute of Medical Sciences and SUM Hospital, Siksha 'O' Anusandhan University, Bhubaneswar, Odisha.

\section{ABSTRACT}

Pseudocyst of pinna is a benign cystic swelling in the anterior part of the auricular cartilage due to intra-cartilaginous accumulation of fluid. This condition is prone to recurrences even after complete drainage of the intra-cartilaginous fluid by several available surgical procedures.

\section{AIM}

Clinical study and comparison of different modalities of approaches for management of pseudocyst of pinna and adoption of a suitable method of treatment that has the least chance of recurrence.

\section{MATERIAL AND METHODS}

80 patients presenting with pseudocyst of the pinna between March 2008 and December 2015 to the Department of Ear, Nose and Throat of Institute of Medical Sciences and SUM Hospital, Bhubaneswar, Odisha, were clinically examined and after the diagnosis was made they were selected for different treatment modalities. The patients were followed up for three months in the postoperative period.

\section{RESULTS}

The pseudocysts were most commonly seen in the age group of 31 to 40 years. Males were more frequently affected with the disease than females. No definite aetiological factor responsible for the disease could be determined in most of the cases, whereas trauma was the second most common cause. The scaphoid fossa with the triangular fossa was the most common site involved. The highest recurrence rate was observed in aseptic aspiration with pressure bandage in 55\% of cases. Surgical de-roofing with compression buttoning and aseptic aspiration with compression buttoning were associated with the lowest recurrence rate seen in $5 \%$ of patients of each group.

\section{CONCLUSION}

Among different surgical procedures with varied rates of recurrences, aseptic aspiration followed by compression buttoning and surgical de-roofing followed by compression buttoning were found to be almost equally effective procedures with the former having definite advantage of being a cosmetically acceptable, less time consuming and cost-effective modality of management.

\section{KEYWORDS}

Pseudocyst, Pinna, Treatment Modalities.

HOW TO CITE THIS ARTICLE: Pani SK, Das SR, Panigrahi D. A comparative study of treatment modalities for pseudocyst of pinna in a teaching Hospital. J. Evolution Med. Dent. Sci. 2016;5(63):4454-4456, DOI: 10.14260/jemds/2016/1016

\section{INTRODUCTION \\ Pseudocyst of pinna is a rare and benign cystic swelling, which results from intra-cartilaginous accumulation of fluid in the anterior part of the auricular cartilage. The scaphoid fossa, triangular fossa of the antihelix and the cymba concha are the usual sites to be involved. Endochondral pseudocyst, intra- cartilaginous auricular seroma cyst, cystic chondromalacia, and benign idiopathic cystic chondromalacia are various terminologies given to this disease. ${ }^{1}$}

Financial or Other, Competing Interest: None.

Submission 18-06-2016, Peer Review 22-07-2016,

Acceptance 29-07-2016, Published 06-08-2016.

Corresponding Author:

Dr. Saumya Ranjan Das,

Professor,

Department of ENT,

Institute of Medical Sciences and SUM Hospital,

Siksha ' $O$ ' Anusandhan University, K-8, Kalinga Nagar,

Bhubaneswar-751003, Odisha, India.

E-mail: saumya.ranjandas3@gmail.com

DOI: $10.14260 / \mathrm{jemds} / 2016 / 1016$
Moreover, pseudocysts are usually unilateral lesions, about 1 to $5 \mathrm{~cm}$ in diameter containing clear to viscous pale yellow fluid, more commonly affecting males than females and the mean age of presentation is $35-40$ years. $^{2}$ Although, the aetiology of pseudocyst is unknown, repeated minor injuries or cartilaginous degeneration caused by the release of chondrocyte lysosomal enzymes are considered to be responsible for this condition. ${ }^{3}$

The name pseudocyst is attributed to its histological characteristics of an intra-cartilaginous cavity lacking an epithelial lining. It is also associated with irregular thinning and hyalinization of the cartilage adjacent to the cavity. Intracartilaginous fibrosis and granulation tissue are usual histological features in later stages of the disease. ${ }^{4}$

Preservation of the anatomical architecture of the pinna along with prevention of recurrence is the ideal treatment for this disease. There are various treatment modalities available for pseudocysts like incisional drainage followed by chemical obliteration methods, such as intra-cartilaginous trichloroacetic acid or intra-lesional corticosteroids and 
mechanical obliteration methods such as pressure dressing with button bolsters or compression suture therapy. The deroofing technique characterized by resection of the anterior cartilaginous leaflet of the pseudocysts with repositioning of the overlying skin flap followed by buttoning had been reported to have good results with least recurrences. 5

\section{MATERIALS AND METHODS}

80 patients presented with pseudocyst of the pinna to the Department of Ear, Nose and Throat of Institute of Medical Sciences and SUM Hospital, Bhubaneswar, Odisha, between March 2008 and December 2015 (Fig. 1). The patients were randomly divided into 4 groups, each group containing 20 patients each, selected for the following procedures.

1. Aseptic aspiration with pressure bandage.

2. Incision and drainage with pressure bandage.

3. Surgical de-roofing with compression buttoning.

4. Aseptic aspiration with compression buttoning.

Aseptic aspirations were performed by aspirating the intra-cartilaginous fluid by a syringe, whereas in incision and drainage method incision was made through the skin and the anterior perichondrium of the cartilage to drain the fluid. The pressure bandages were kept for 72 hours, whereas the compression buttons were kept for 10 days (Fig. 2). All the patients were subjected to 3 months of post-operative follow-up.

\section{Inclusion and Exclusion Criteria}

Patients with pseudocysts of pinna having features of unilateral, painless, non-tender, smooth swelling on the anterior aspect of pinna were included in the study. The patients with signs of local infection, fibrosis, scarring, tenderness, ulcerated surface and recurrences as well as general conditions such as pregnancy, diabetes, hypertension and systemic diseases were excluded from the present study.

\section{OBSERVATIONS}

The present study revealed that pseudocysts were most commonly encountered in the age group of $31-40$ years (40\%). Out of 80 cases, 58 (72.5\%) were males and 22 (27.5\%) were females (Table 1). In 44 patients (55\%), no definite aetiological factor responsible for the disease could be determined, whereas trauma was the second most common cause $(23.75 \%)$ associated with the disease (Table 2$)$. The scaphoid fossa with the triangular fossa was the most common site of pinna (42.5\%) involved in pseudocyst formation (Table 3). Out of the 4 treatment modalities, the highest recurrence rate (55\%) was observed in aseptic aspiration with pressure bandage. Surgical de-roofing with compression buttoning and aseptic aspiration with compression buttoning were associated each with the lowest frequency (5\%) of recurrence (Table 4). Post-operative perichondritis was encountered in one patient undergoing incision and drainage with pressure bandage procedure, which could be treated with daily dressing and medications for 10 days.

\begin{tabular}{|c|c|c|c|c|}
\hline $\begin{array}{c}\text { Age in } \\
\text { Years }\end{array}$ & $\begin{array}{c}\text { No. of } \\
\text { Patients }\end{array}$ & Percentage & Males & Females \\
\hline $11-20$ & 8 & 10 & 5 & 3 \\
\hline $21-30$ & 22 & 27.5 & 16 & 6 \\
\hline $31-40$ & 32 & 40 & 24 & 8 \\
\hline $41-50$ & 11 & 13.75 & 7 & 4 \\
\hline $51-60$ & 4 & 5 & 3 & 1 \\
\hline $61-70$ & 2 & 2.5 & 2 & - \\
\hline $71-80$ & 1 & 1.25 & 1 & - \\
\hline Total & 80 & 100 & 58 & 22 \\
\hline \multicolumn{7}{|c|}{ Table 1: Age and Sex Distribution of Patients with } \\
Pseudocyst of Pinna \\
\hline
\end{tabular}

\begin{tabular}{|c|c|c|}
\hline Pre-Disposing Factors & $\begin{array}{c}\text { No. of } \\
\text { Patients }\end{array}$ & $\begin{array}{c}\text { Percentage } \\
(n=80)\end{array}$ \\
\hline Slap/boxing/blunt trauma & 19 & 23.75 \\
\hline Massage/rubbing & 4 & 5 \\
\hline Pulling of pinna & 3 & 3.75 \\
\hline $\begin{array}{c}\text { Sleeping in awkward } \\
\text { position or on hard pillow }\end{array}$ & 6 & 7.5 \\
\hline Wearing tight helmets & 4 & 5 \\
\hline Nothing suggestive & 44 & 55 \\
\hline \multicolumn{3}{|c|}{$\begin{array}{c}\text { Table 2: Predisposing Factors in Patients with } \\
\text { Pseudocyst of Pinna }\end{array}$} \\
\hline
\end{tabular}

\begin{tabular}{|c|c|c|}
\hline $\begin{array}{c}\text { Site of } \\
\text { Involvement }\end{array}$ & $\begin{array}{c}\text { No. of } \\
\text { Patients }\end{array}$ & $\begin{array}{c}\text { Percentage } \\
(n=80)\end{array}$ \\
\hline Scaphoid fossa & 18 & 22.5 \\
\hline Triangular fossa & 14 & 17.5 \\
\hline $\begin{array}{l}\text { Scaphoid fossa } \\
\text { with } \\
\text { triangular fossa }\end{array}$ & 34 & 42.5 \\
\hline Cymba concha & 9 & 11.25 \\
\hline Diffuse & 5 & 6.25 \\
\hline
\end{tabular}

\begin{tabular}{|c|c|c|c|}
\hline Procedure & $\begin{array}{c}\text { Total } \\
\text { Number } \\
\text { of } \\
\text { Patients }\end{array}$ & $\begin{array}{c}\text { Number of } \\
\text { Patients } \\
\text { with } \\
\text { Recurrence } \\
\text { of Disease } \\
\end{array}$ & $\begin{array}{c}\text { Percentage } \\
(n=20)\end{array}$ \\
\hline $\begin{array}{c}\text { Aseptic } \\
\text { aspiration } \\
\text { with pressure } \\
\text { bandage }\end{array}$ & 20 & 11 & 55 \\
\hline $\begin{array}{c}\text { Incision and } \\
\text { drainage with } \\
\text { pressure } \\
\text { bandage }\end{array}$ & 20 & 7 & 35 \\
\hline $\begin{array}{l}\text { Surgical de- } \\
\text { roofing with } \\
\text { compression } \\
\text { buttoning }\end{array}$ & 20 & 1 & 5 \\
\hline $\begin{array}{c}\text { Aseptic } \\
\text { aspiration } \\
\text { with } \\
\text { compression } \\
\text { buttoning }\end{array}$ & 20 & 1 & 5 \\
\hline Table 4: Rat & $\begin{array}{l}\text { Recurr } \\
\text { Pseudo }\end{array}$ & $\begin{array}{l}\text { of Surgical } \\
\text { of Pinna }\end{array}$ & cedures in \\
\hline
\end{tabular}




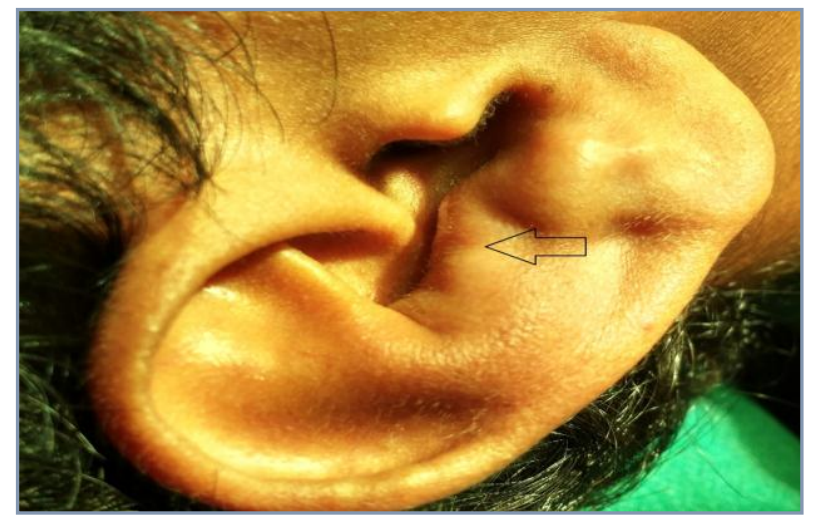

Fig. 1: Pseudocyst of Pinna (Arrow)
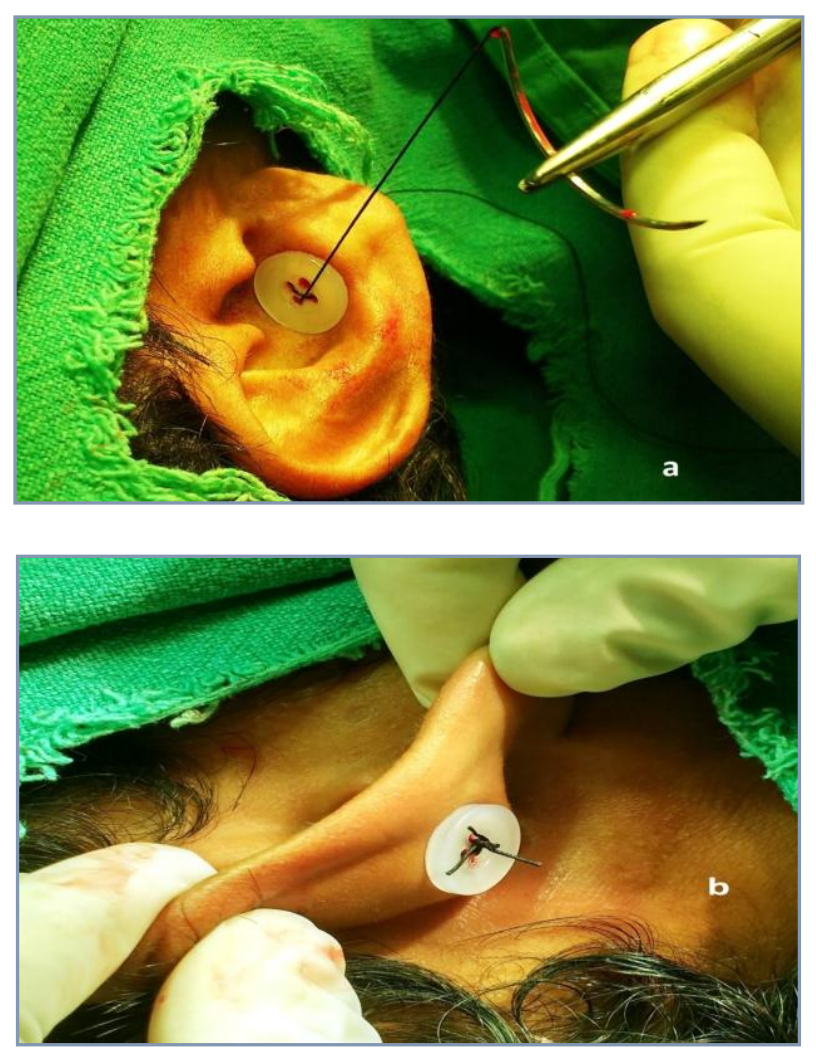

Fig. 2: Aseptic Aspiration of Pseudocyst Pinna with Compression Buttoning, a: Anterior View, b: Posterior View

\section{DISCUSSION}

Pseudocysts of pinna usually occur in the anterior and superior part of auricular cartilage, the most common site being the scaphoid fossa. The disease is frequently associated with a history of trauma. ${ }^{6}$ The present study revealed that the pseudocysts occurred at the scaphoid fossa with triangular fossa of pinna without any evident aetiological factor in most of the cases. As per a study, the aim of management of the condition is to restore the normal appearance of pinna that could be achieved by removal of the cystic content by aspiration or incision followed with induction of fibrosis of intra-cartilaginous cavity reinforced by bilateral pressure dressing.7; 85.41\% patients in a study showed recurrence of the condition within 10 days after needle aspiration and intralesional steroid injection and contour dressing, whereas $26.9 \%$ of patients had recurrence after incision and drainage with buttoning. No recurrence was encountered in patients undergoing surgical de-roofing with buttoning.8 This observation was similar to the present study, which revealed that the highest recurrence rate was observed in aseptic aspiration with pressure bandage (55\%), whereas surgical deroofing with compression buttoning and aseptic aspiration with compression buttoning were each associated with the lowest frequencies of recurrence (5\%).

\section{CONCLUSION}

Although several surgical procedures are available for the treatment of pseudocysts of pinna with varied results, aseptic aspiration followed by compression buttoning and surgical deroofing followed by compression buttoning have almost equal results, the former having the advantage of being a cosmetically acceptable, less time consuming and costeffective procedure with less chances of complications.

\section{ACKNOWLEDGEMENT}

We are grateful to Prof. G. Sahoo, Dean; and Mr. G. Kar, Managing Member, IMS and SUM Hospital for encouragements and facilities.

\section{REFERENCES}

1. Ramadass T, Ayyaswamy G. Pseudocyst of auricle aetiopathogenesis, treatment update and literature review. Indian J Otolaryngol Head Neck Surg 2006;58(2):156-9.

2. Khan NA, Islam MU, Rehman AU, et al. Pseudocyst of pinna and its treatment with surgical de-roofing: an experience at tertiary hospitals. J of Surg Tech Case Report 2013;5(2):72-7.

3. Supiyaphun $P$, Decha $W$, Kerekhanjanarong V, et al. Auricular pseudocysts: a treatment with the chulalongkorn university vacuum device. Otolaryngol Head Neck Surg 2001;124(2):213-6.

4. Lee JA, Panarese A. Endochondral pseudocyst of the auricle. J Clin Pathol 1994;47(10):961-3.

5. Lee YK, Ku BS, Kim YH. A case of pseudocyst of the auricle treated by incisional biopsy. Korean J Dermatol 2007;45(5):518-20.

6. Giles WC, Iverson KC, King JD, et al. Incision and drainage followed by mattress suture repair of auricular hematoma. Laryngoscope 2007;117(12):2097-9.

7. Cohen PR, Katz BE. Pseudocyst of the auricle: successful treatment with intracartilaginous trichloroacetic acid and button bolsters. J Dermatol Surg Oncol 1991;17(3):255-8.

8. Rehman A, Sangoo MA, Hamid S, et al. Recurrent pseudocyst pinna: a rational approach to treatment. Int J Scientific and Research Publications 2013;3(7):1-4. 